\author{
S. Yevseiev, S. Pohasii, V. Khvostenko
}

\author{
Simon Kuznets Kharkiv National University of Economics, Kharkiv
}

\title{
DEVELOPMENT OF A PROTOCOL FOR A CLOSED MOBILE INTERNET CHANNEL BASED ON POST-QUANTUM ALGORITHMS
}

The development of computing technologies has made it possible not only to expand the range of mobile communication services, but also to significantly increase computing capabilities. The emergence of mobile Internet, $4 G, 5 G$ technologies makes it possible to talk about a fundamentally different approach to ensuring the quality of service to network customers, creating fundamentally new approaches to ensuring the efficiency and reliability of transmitted information flows. However, such a rapid growth of GSM technologies without the introduction of security services leads to active actions of attackers and cyber terrorists, the emergence of new and modification of known threats. Mobile communication channels are used by cybercriminals for selfish purposes of access to database resources not only of the mobile Internet, but also to the databases of information and communication systems and networks. The article proposes a fundamentally new approach to ensuring the closure of the voice channel of the mobile Internet based on post-quantum cryptography algorithms - McEliece and Niederreiter crypto-code constructions on elliptic codes. This approach provides not only the offline mode of closing the voice channel and creating a VPN channel in tunnel mode, but also the required level of cryptographic strength in the face of the emergence of full-scale quantum computers.

Keywords: post-quantum cryptoalgorithms, crypto-code constructions of McEliece and Niederreiter, mobile Internet, $4 G, 5 G$ technology.

\section{Introduction}

Computing resources have made it possible to significantly expand the capabilities of mobile (cellular) communications, combining them with cyberspace into a single sphere of ensuring the growing needs of the world community. The development of the $4 \mathrm{G}-6 \mathrm{G}$ mobile radiotelephone network has significantly expanded not only the range of services, but also gradually replaces the usual computer networks with their terminal equipment in the form of workstations, laptops, etc., allowing the use of smartphones as the main gadget of the system. At the same time, not only computational capabilities have increased by 3-5 orders of magnitude, but also the transmission speed of information flows, which significantly affects their widespread use in various areas of development of systems and networks of Internet of things, sensor and Mesh networks.

The main advantage over computer networks of LTE (4G) technology is a high data transfer rate than in IEEE 802.X. However, with all the advantages, there is a significant drawback - the almost complete absence of security services, which largely does not allow users to receive the required level of service quality. This disadvantage is inherent in the new generation networks of $4 \mathrm{G}-6 \mathrm{G}$ technology based on the Diameter protocol. This protocol provides 3A services (identification, authorization and authentication), however, the provision of confidentiality services (ensuring the protection of information during transmission from passive attacks), and integrity (ensuring protection during storage and the possibility of modification only by an authorized user in networks based on the Diameter protocol is not provided). This approach allows attackers to use mobile Internet channels not only as channels of information leakage, but also as the main channels of access to computer networks and systems [1-6].

To ensure privacy on the mobile Internet, cryptographic symmetric algorithms are usually used, while developers are forced to change transmission protocols to ensure the protection of voice messages in offline mode, which significantly affects their widespread use. So when using cryptophones, it is necessary for the interlocutors to have the appropriate gadgets of a certain model, which significantly reduces their widespread use [7].

In addition, symmetric and asymmetric cryptosystems are used to ensure cryptographic strength in these gadgets. However, with the advent of a full-scale quantum computer based on Shor's and Grover's algorithms, such systems can significantly reduce the level of security or be hacked in polynomial time [1]. Thus, in the context of the rapid growth of computing technologies and the capabilities of quantum computers, the emergence of targeted threats based on the combination of threats with signs of synergy and hybridity with social engineering methods, the urgent task is to create new approaches and / or improve the known security in mobile technologies and networks based on mobile Internet channels.

Analysis of the last research and publications. To provide security services in the post-quantum period, it is necessary to introduce new post-quantum cryptog- 
raphy algorithms. To this end, the US National Institute of Standards and Technology (NIST) opened a competition for post-quantum cryptography algorithms in February 2019. At the third stage, among the four applicants for an asymmetric post-quantum cryptography algorithm, the classical scheme of McEliece's cryptocode construction is presented. However, in [8], the studies carried out confirm that the construction of a classical scheme that will provide the required level of resistance in the post-quantum period is necessary over

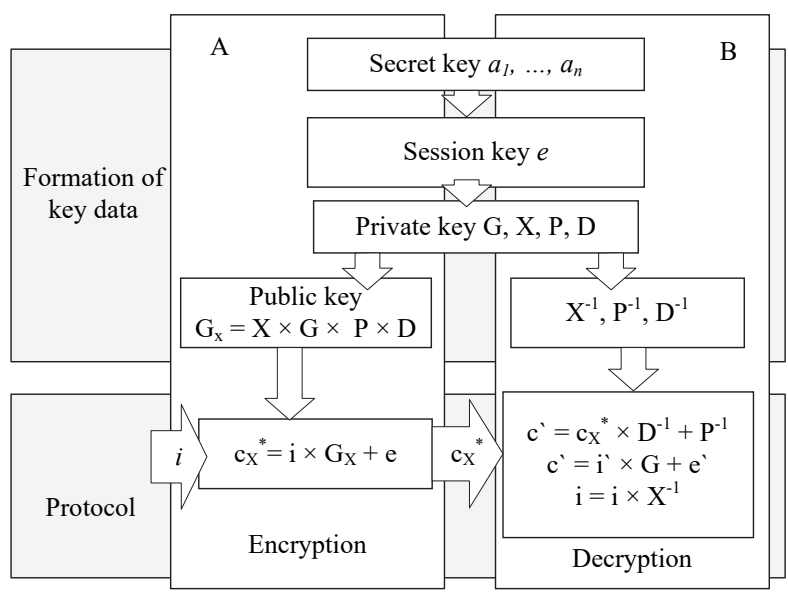

Fig. 1. Exchange protocol based on a modified McEliece crypto-code system on modified EC
GF $\left(2^{10}-2^{13}\right)$, which significantly narrows their application. In order to eliminate this drawback, the works [811] proposed schemes of crypto-code constructions by McEliece and Niederreiter on modified elliptic codes (algebraic geometric codes based on coding theory algorithms using elliptic curve parameters). Fig. 1 and 2 show modified CCC (MCCC) McEliece and Niederreiter on modified elliptic codes (MEC). Table 1-2 shows the design parameters of the MEC, and crypto-code constructions, respectively.

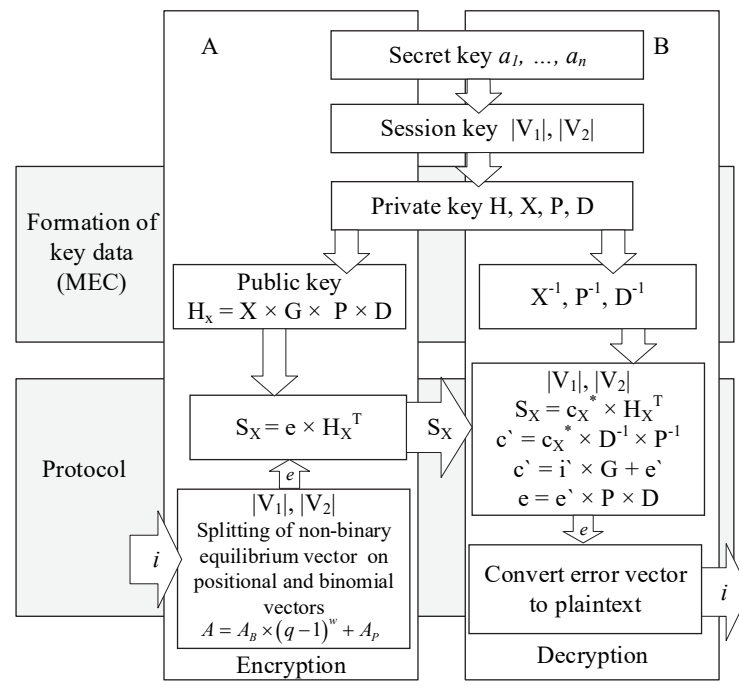

Fig. 2. Exchange protocol based on a modified Niederreiter crypto-code system on modified EC

Table 1

The main $(n, k, d)$ properties of $M E C$

\begin{tabular}{|c|c|c|}
\hline Property & Shortened MEC & Extended MEC \\
\hline $\begin{array}{l}(n, k, d) \text { code parameters } \\
\text { constructed by displaying } \\
\text { the view } \varphi: \mathrm{X} \rightarrow \mathrm{P}^{\mathrm{k}-1}\end{array}$ & $\begin{array}{c}n=2 \sqrt{q}+q+1-x, \\
k \geq \alpha-x, d \geq n-\alpha, \\
\alpha=3 \times \operatorname{deg} F, \\
k+d \geq n\end{array}$ & $\begin{array}{c}n=2 \sqrt{q}+q+1-x+x_{1}, \\
k \geq \alpha-x+x_{1}, d \geq n-\alpha, \\
\alpha=3 \times \operatorname{deg} F\end{array}$ \\
\hline $\begin{array}{l}(n, k, d) \text { code parameters } \\
\text { constructed by displaying } \\
\text { the view } \varphi: \mathrm{X} \rightarrow \mathrm{P}^{\mathrm{r}-1}\end{array}$ & $\begin{array}{c}n=2 \sqrt{q}+q+1-x, \\
k \geq n-\alpha, d \geq \alpha, \\
\alpha=3 \times \operatorname{deg} F, k+d \geq n\end{array}$ & $\begin{array}{c}n=2 \sqrt{q}+q+1-x+x_{1} \\
k \geq n-\alpha, d \geq \alpha \\
\alpha=3 \times \operatorname{deg} F\end{array}$ \\
\hline
\end{tabular}

Table 2

Basic parameters of McEliece MCCC on $M E C$

\begin{tabular}{|c|c|c|}
\hline Property & Shortened MEC & Extended MEC \\
\hline dimension of the secret key & $l_{K+}=x \times\left\lceil\log _{2}(2 \sqrt{q}+q+1)\right.$ & $l_{K+}=\left(x-x_{1}\right) \times \log _{2}(2 \sqrt{q}+q+1)$ \\
\hline $\begin{array}{c}\text { dimension of information } \\
\text { vector }\end{array}$ & $l_{I}=(\alpha-x) \times m$ & $l_{I}=\left(\alpha-x+x_{1}\right) \times m$ \\
\hline dimension of the cryptogram & $l_{S}=(2 \sqrt{q}+q+1-x) \times m$ & $l_{S}=\left(2 \sqrt{q}+q+1-x+x_{1}\right) \times m$ \\
\hline relative transmission speed & $R=(\alpha-x) /(2 \sqrt{q}+q+1-x)$ & $R=\left(\alpha-x+x_{1}\right) /\left(2 \sqrt{q}+q+1-x+x_{1}\right)$ \\
\hline
\end{tabular}

The proposed McEliece MCCC can reduce the power of the alphabet, which allows them to be implemented in practice, while ensuring the required level of cryptographic strength due to the introduction of addi- tional initialization vectors: $I V_{1}-$ defines shortening characters from a code word (cryptograms), $I V_{2}-$ defines elongation characters (plain text) of a code word (cryptogram). 


\section{Statement of basic materials}

To close the GSM voice channel, it is proposed to use a hardware and software complex that provides offline confidentiality of voice messages on the basis of post-quantum encryption algorithms - McEliece and Niederreiter crypto-code constructions on algebraic geometric codes. The block diagram of the communication organization is shown in Fig. 3.

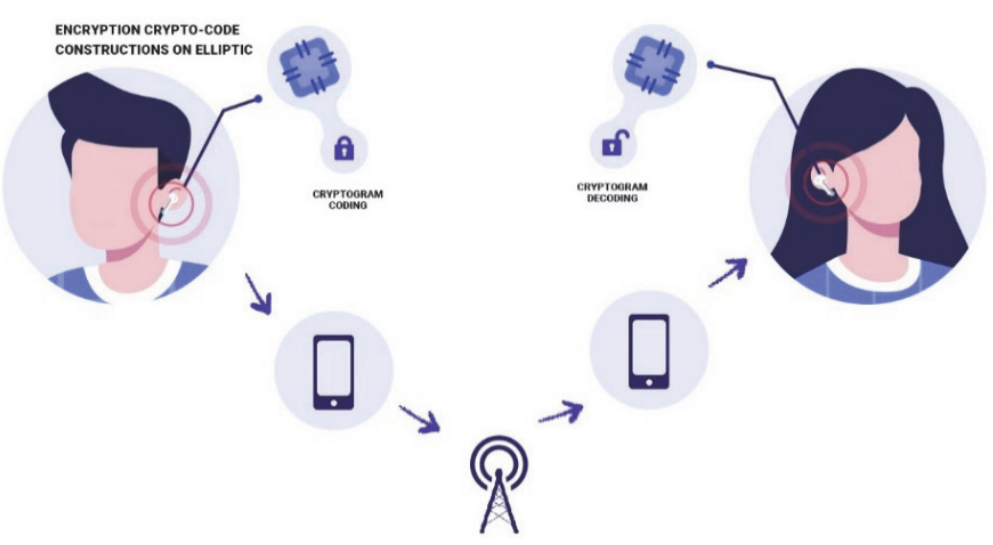

Fig. 3. Block diagram of GSM voice channel closure

To ensure the closure, specialized chipsets are used in which encryption algorithms are implemented based on the McEliece crypto-code construction. In this case, the analog signal of the message after entering the headset is converted into digital form and immediately goes to the encoder. The encrypted message is transmitted via the Bluetooth channel to the mobile gadget. After that, the protocols of the GSM mobile Internet channel are used. This approach makes it possible to use standard procedures for subsequent transformations, ignore manufacturers and modifications of both headsets and mobile gadgets, and ignore modifications of both the Bluetooth channel and the mobile Internet technology. In addition, it can significantly reduce the cost of production and implementation of this approach.

To implement the protocol for closing a voice GSM channel, it is proposed to use a mobile messenger and a key data server presented in Fig. 4. The complex of means of protection is built taking into account the most modern developments in the field of post-quantum cryptography based on crypto-code constructions. At the same time, the complex provides maximum protection of your conversations from unauthorized access. To ensure security, only the session password is recorded in the headphones, depending on the role (sender, recipient), which are recorded from the mobile application. After the end of the conversation, they are deleted.

To ensure the security of the transmission of key data for conducting a conversation, the channel between the mobile application and the server is encrypted based on an asymmetric cryptosystem - a post-quantum algorithm of the Niederreiter crypto-code construction.

To ensure the security of the server side, after the keys are generated for the conversation and their transfer to the sender and the recipient, the RAM is reset to zero. The secret keys of the McEliece and Niederreiter crypto-code constructions change with different periods of time. Consider a voice message security protocol based on post-quantum algorithms:

\section{CALLER A (initiator of the call)}

1. Opens the telephone line software and finds the corresponding caller in the list of callers (CALLER B).

2. Sends a request to caller $B$ through the server.

3. Receives on the phone software through a private channel (encryption based on the Niederreiter's $\mathrm{CCC}$ in the EC is used) a private key, and a public key of caller B.

4. Confirms the willingness to talk. In this case, the personal key (KRA) and the public key KUB are transmitted from the phone software via the Bluetooth channel.

5. The key is recorded in the Bluetooth headset in the encoder (C/DC).

6. After recording the key, a ready signal is generated.

7. After confirmation of the readiness of caller B, the conversation is carried out.

SERVER SOFTWARE

1. At the request of subscriber $\mathrm{A}$ in (2), the CCC key selection generator randomly selects the key parameters and transmits it to (1).

2. In (1) secret keys are received from HSM (masking matrices - X, P, D, and generating matrix GEC).

3. In (1), $\mathrm{KR}_{\mathrm{A}}$ (personal key of McEliece CCC of caller $\mathrm{A}$ ) and $\mathrm{KU}_{\mathrm{A}}$ (public key of caller $\mathrm{A}$ ) are generated.

4. At the response of caller $\mathrm{B}$, a public key $\mathrm{KU}_{\mathrm{B}}$ is generated and transmitted to caller $\mathrm{A}$.

5. The generated KRA and $\mathrm{KU}_{\mathrm{A}}$ come to (3) from (1), after the keys are transferred to (1), the data is erased. 
6. In (3) $\mathrm{KR}_{\mathrm{A}}$ and $\mathrm{KU}_{\mathrm{A}}, \mathrm{KU}_{\mathrm{B}}$ are encrypted.

7. From (3), respectively, $\mathrm{KR}_{\mathrm{A}}, \mathrm{KU}_{\mathrm{B}}$ are sent to caller $\mathrm{A}$ (the caller who initiates the call), $\mathrm{KU}_{\mathrm{A}}$ - to caller B (the caller who is called), after the keys are transferred to (3), the data is erased.

\section{CALLER B (call recipient)}

1. Receives a request from the server to the phone software to transfer the public key $\left(\mathrm{KU}_{\mathrm{A}}\right)$.

2. Confirms the request to the server, sends $K_{B}$.

3. Receives the public key $\mathrm{KU}_{\mathrm{A}}$ to the phone software through a private channel (encryption based on the Niederreiter CCC on the EC is used).

4. Confirms the willingness to talk. In this case, the public key $\left(\mathrm{KU}_{\mathrm{A}}\right)$ is transmitted from the phone software via the Bluetooth channel.
5. In the Bluetooth headphones, the key is recorded in the decoder (C/DC).

6. After recording the key, a ready signal is generated.

7. After confirming that it is ready, caller B sends a signal to the server that it is ready to talk.

Thus, the proposed protocol ensures the closure of the mobile Internet channel using a complex of software and hardware. The use of a hardware solution for closing (encrypting) a voice message in a headset will provide resistance to almost all threats, and the use of a key server provides a tunnel mode, which excludes the possibility of "eavesdropping" of voice messages.

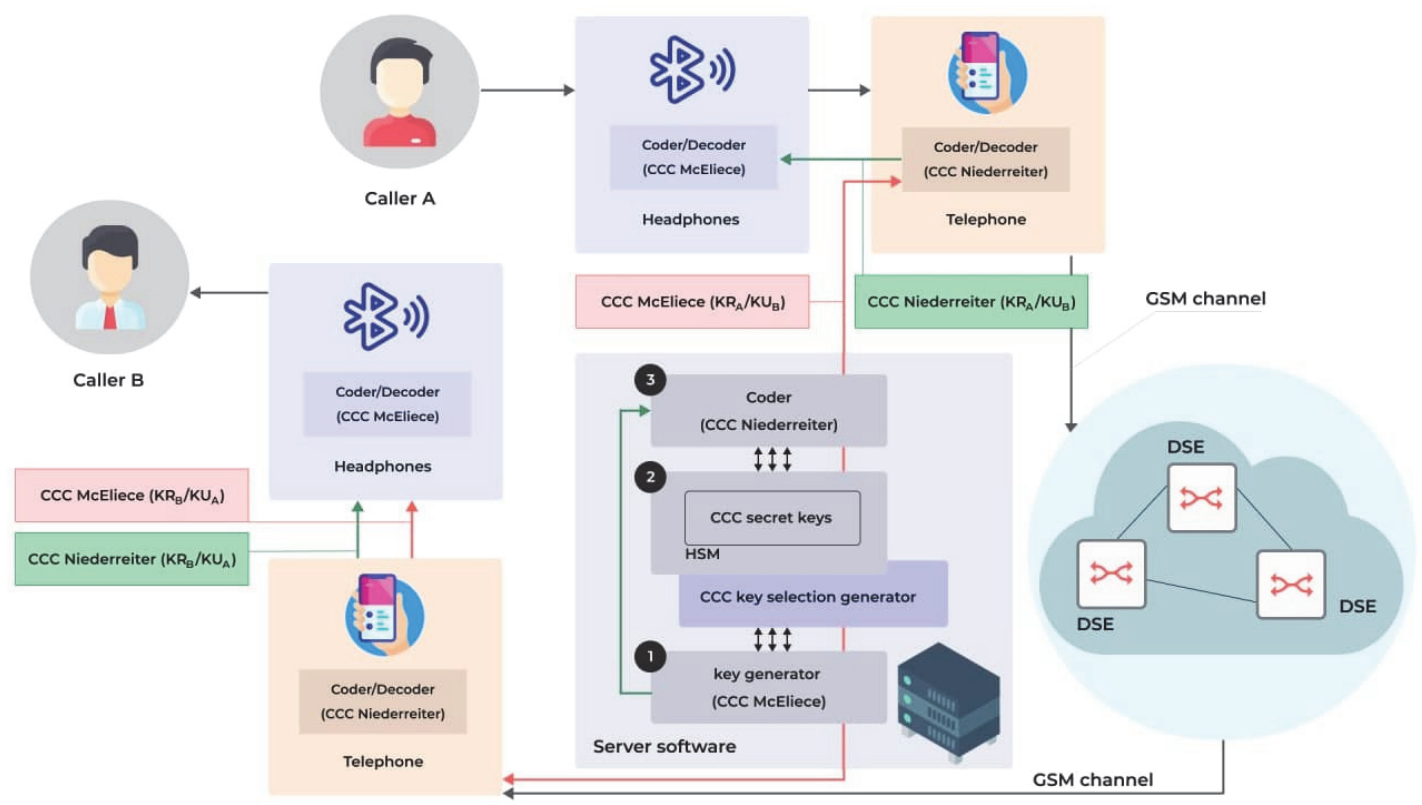

Fig. 4. Block diagram of the protocol for closing a voice GSM-channel based on CCC

\section{Conclusion}

1. Today, mobile applications based on GSM technologies and LTE / SAE technologies lack mechanisms that provide security services - confidentiality and integrity. The advent of a full-blown quantum computer will allow attackers to break cryptographic-based security protocols in a fraction of the time. Any of us, from an employee of a private company to huge corporations, can face the problem of unauthorized recording (wiretapping). The relevance of threats associated with secret communications grows with the growth of business and career. This, in turn, leads to a number of risks: from reputational damage to the individual or the company as a whole. The proposed hardware and software complex allows to ensure personal confidentiality of conversations in a mobile environment. The complex provides maximum protection of voice information from unauthorized access and wiretapping during conversations. The complex makes it possible to quickly respond to growing threats due to a high-performance security kernel.

2 . The conducted studies of post-quantum cryptography algorithms based on crypto-code constructions confirm that the use of MEC (EC) provides performance at the level of the speed of crypto-transformations of symmetric cryptoalgorithms, evidence-based cryptographic strength based on the complexity-theoretic problem of decoding a random code (secured $10^{30}-10^{35}$ group operations), and reliability based on the use of a shortened algebraic geometric code (secured $P_{\text {error }}=10^{-9}-$ $\left.10^{-12}\right)$.

\section{References}

1. Chen, L., Jordan, S., Liu, Yi-Kai, Moody, D., Peralta, R., Perlner, R. and Smith-Tone, D. (2016), Report on PostQuantum Cryptography, available at: www.nvlpubs.nist.gov/nistpubs/ir/2016/NIST.IR.8105.pdf. 
2. "Protokol DIAMETR. Tehnicheskie materialy IBM" [DIAMETR protocol. IBM technical materials], available at: www.ibm.com/developerworks/ru/library/wi-diameter/ (accessed 20.04.2020).

3. Ankur Lohachab, Anu Lohachab and Ajay Jangra (2020), A Comprehensive Survey of Prominent Cryptographic Aspects for Securing Communication in Post-Quantum IoT Networks, Internet of Things, Vol. 9. https://doi.org/10.1016/j.iot.2020.100174.

4. Positive Technologies (2017), "Ugrozy bezopasnosti jadra paketnoj seti 4G" [4G packet core security threats], available at: https://www.ptsecurity.com/ru-ru/research/analytics/epc-2017/ (accessed 20.04.2020).

5. Positive Technologies (2018), "Ujazvimosti protokola Diameter $v$ setjah 4G" [Diameter protocol vulnerabilities in $4 G$ networks], available at: https://www.ptsecurity.com/ru-ru/research/analytics/diameter-2018/ (accessed 20.04.2020).

6. Stepanova, I.V., Ahmed Abdulvasea and Ndajinkunda Zhuv (2015), "Analiz perspektivnyh podhodov k povysheniju nadezhnosti konvergentnyh korporativnyh setej svjazi" [Analysis of promising approaches to improving the reliability of converged corporate communication networks], T-Comm: Telekommunikacii i transport, Vol. 9, No. 12, pp. 44-51.

7. "Kriptofony: obzor smartfonov so vstroennoj podderzhkoj blokchejna" [Cryptophones: an overview of smartphones with built-in blockchain support], available at: https://zen.yandex.ru/media/id/5d39a870e6cb9b00ad2c6c63/kriptofony-obzorsmartfonov-so-vstroennoi-podderjkoi-blokcheina-5d8676819c94465af4ba9185.

8. Yevseiev, S., Ponomarenko, V., Laptiev, O. and Milov, O. (2021), Synergy of building cybersecurity systems: monograph, PC TECHNOLOGY CENTER, Kharkiv, $188 \mathrm{p}$.

9. Yevseiev, S., Tsyhanenko, O., Gavrilova, A., Guzhva, V., Milov, O. and Moskalenko, V. (2019), Development of Niederreiter hybrid crypto-code structure on flawed codes, Eastern-European Journal of Enterprise Technologies, No. 1(9(97)), pp. 27-38. https://doi.org/10.15587/1729-4061.2019.156620.

10. Yevseiev, S., Tsyhanenko, O., Ivanchenko, S., Aleksiyev, V., Verheles, D. and Volkov, S. (2018), Practical implementation of the Niederreiter modified crypto-code system on truncated elliptic codes, Eastern-European Journal of Enterprise Technologies, No. 6(4(96)), pp. 24-31. https://doi.org/10.15587/1729-4061.2018.150903.

11. Yevseiev, S., Kots, H. and Liekariev, Y. (2016), Developing of multi-factor authentication method based on niederreiter-mceliece modified crypto-code system, Eastern-European Journal of Enterprise Technologies, No. 6(4(84)), pp. 11-23. https://doi.org/10.15587/1729-4061.2016.86175.

\section{Список літератури}

1. Chen L., Jordan S., Liu Yi-Kai, Moody D., Peralta R., Perlner R., Smith-Tone, D. Report on Post-Quantum Cryptography. 2016. URL: http://nvlpubs.nist.gov/nistpubs/ir/2016/NIST.IR.8105.pdf.

2. Протокол DIAMETR. Технические материалы IBM: веб-сайт. URL: http://www.ibm.com/developerworks/ru/library/wi-diameter/ (дата обращения: 20.04.2020).

3. Ankur Lohachab, Anu Lohachab, Ajay Jangra. A Comprehensive Survey of Prominent Cryptographic Aspects for Securing Communication in Post-Quantum IoT Networks. Internet of Things. 2020. Vol. 9. https://doi.org/10.1016/j.iot.2020.100174.

4. Угрозы безопасности ядра пакетной сети 4G. 2017. веб-сайт. URL: https://www.ptsecurity.com/ruru/research/analytics/epc-2017/. (дата обращения: 20.04.2020).

5. Уязвимости протокола Diameter в сетях 4G. 2018. веб-сайт. URL: https://www.ptsecurity.com/ruru/research/analytics/diameter-2018/ (дата обращения: 20.04.2020).

6. Степанова И. В. Ахмед Абдулвасеа, Ндайинкунда Жув. Анализ перспективных подходов к повышению надежности конвергентных корпоративных сетей связи. Т-Сотm: Телекоммуникаиии и транспорт. 2015. Том 9. № 12. Р. 4451 .

7. Криптофоны: обзор смартфонов со встроенной поддержкой блокчейна. веб-сайт. URL: https://zen.yandex.ru/media/id/5d39a870e6cb9b00ad2c6c63/kriptofony-obzor-smartfonov-so-vstroennoi-podderjkoi-blokcheina$5 \mathrm{~d} 8676819 \mathrm{c} 94465 \mathrm{af} 4 \mathrm{ba} 9185$.

8. Yevseiev S., Ponomarenko V., Laptiev O., Milov O. Synergy of building cybersecurity systems: monograph. Kharkiv : PC TECHNOLOGY CENTER, 2021. 188 p.

9. Yevseiev S., Tsyhanenko O., Gavrilova A., Guzhva V., Milov O., Moskalenko V. Development of Niederreiter hybrid crypto-code structure on flawed codes. Eastern-European Journal of Enterprise Technologies. 2019. No. 1(9(97)). P. 27-38. https://doi.org/10.15587/1729-4061.2019.156620.

10. Yevseiev S., Tsyhanenko O., Ivanchenko S., Aleksiyev V., Verheles D., Volkov S. Practical implementation of the Niederreiter modified crypto-code system on truncated elliptic codes. Eastern-European Journal of Enterprise Technologies. 2018. No. 6(4(96)). P. 24-31. https://doi.org/10.15587/1729-4061.2018.150903.

11. Yevseiev S., Kots H., Liekariev, Y. Developing of multi-factor authentication method based on niederreiter-mceliece modified crypto-code system. Eastern-European Journal of Enterprise Technologies. 2016. No. 6(4(84)). P. 11-23. https://doi.org/10.15587/1729-4061.2016.86175.

\section{Відомості про авторів:}

\section{Свсєєв Сергій Петрович}

доктор технічних наук старший науковий співробітник завідувач кафедри

Харківського національного

економічного університету ім. С. Кузнеця,

Харків, Україна

https://orcid.org/0000-0003-1647-6444

\section{Information about the authors:}

\section{Serhii Yevseiev}

Doctor of Technical Sciences Senior Research

Head of the Department

of Simon Kuznets Kharkiv National

University of Economics,

Kharkiv, Ukraine

https://orcid.org/0000-0003-1647-6444 
Погасій Сергій Сергійович

кандидат економічних наук доцент доцент кафедри Харківського національного економічного університету ім. С. Кузнеця, Харків, Україна https://orcid.org/0000-0002-4540-3693

Хвостенко Владислав Сергійович кандидат економічних наук доцент доцент кафедри Харківського національного економічного університету ім. С. Кузнеця, Харків, Україна https://orcid.org/0000-0002-6436-4159

\section{Serhii Pohasii}

$\mathrm{PhD}$ Associate Professor

Senior Lecturer of Simon Kuznets

Kharkiv National University of Economics, Kharkiv, Ukraine

https://orcid.org/0000-0002-4540-3693

\author{
Vladyslav Khvostenko \\ $\mathrm{PhD}$ in Economics Associate Professor \\ Senior Lecturer of Simon Kuznets \\ Kharkiv National University of Economics, \\ Kharkiv, Ukraine \\ https://orcid.org/0000-0002-6436-4159
}

\title{
РОЗРОБКА ПРОТОКОЛУ ЗАКРИТОГО МОБІЛЬНОГО ІНТЕРНЕТ-КАНАЛУ НА ОСНОВІ ПОСТКВАНТОВИХ АЛГОРИТМІВ
}

\author{
С.П. Євсеєв, С.С. Погасій, В.С. Хвостенко
}

Розвиток обчислювальних технологій дозволило не тільки розиирити спектр послуг мобільного зв'язку, але $i$ значно збільшити обчислювальні можливості. Поява мобільного Інтернету, технологій $4 G$, $5 G$ дозволяє говорити про принциипово інший підхід забезпечення якості обслуговування клієнтів мережі, створення принципово нових підходів у забезпеченні оперативності та вірогідності переданих інформачійних потоків. Однак таке стрімке зростання технологій GSM без впровадження послуг безпеки призводить до активних дї зловмисників $і$ кібертерористів, появи нових і модифікації відомих загроз. Канали мобільного зв'язку використовуються зловмисниками в корисливих ичілях доступу до ресурсів баз даних не тільки мобільного Інтернету, а й до баз інформаційно-комунікаційних систем $і$ мереж. У статті пропонується принципово новий підхід до забезпечення закриття голосового каналу мобільного Інтернету на основі алгоритмів постквантової криптографії крипто-кодових конструкціях Мак-Еліса і Нідеррайтера на еліптичних кодах. Класична крипто-кодова конструкція Мак-Еліса є учасником третього раунду криптографічного конкурсу цифрового підпису постквантової криптографії, який проводиться NIST США, шуо дозволяє стверджувати про використання крипто-кодових конструкцій в постквантовий період. Крім того, запропоновані крипто-кодові конструкиї Мак-Еліса й Нідеррайтера реалізовані на алгеброгеометрічних кодах, щзо дозволяє уникнути атаки Сідельникова В.М., та підвищити рівень стійкості, а використання модифікованих та/або збиткових кодів дозволяють зменшити енергетичну місткість при практичній їх реалізації. Такий підхід забезпечує не тільки офлайн режим закриття голосового каналу і створення VPN-каналу в тунельному режимі, але $і$ необхідний рівень криптостійкості в умовах появи повномасштабних квантових комп'ютерів.

Ключові слова: постквантовой криптоалгоритми, крипто-кодові конструкиї Мак-Еліса $і$ Нідеррайтера, мобільний Інтернет, технологія $4 G, 5 G$.

\section{РАЗРАБОТКА ПРОТОКОЛА ЗАКРЫТОГО МОБИЛЬНОГО ИНТЕРНЕТ-КАНАЛА НА ОСНОВЕ ПОСТКВАНТОВЫХ АЛГОРИТМОВ}

\section{С.П. Евсеев, С.С. Погасий, В.С. Хвостенко}

Развитие вычислительных технологий позволило не только расширить спектр услуг мобильной связи, но и значительно увеличить вычислительные возможности. Появление мобильного Интернета, технологий 4G, $5 G$ позволяет говорить о принципиально другом подходе обеспечения качества обслуживания клиентов сети, созданию приниипиально новых подходов в обеспечении оперативности и достоверности передаваемых информационных потоков. Однако такой стремительный рост технологий GSM без внедрения услуг безопасности приводит к активным действия злоумышленников и кибертеррористов, появлению новых и модификации известных угроз. Каналь мобильной связи используются злоумышленниками в корыстных иелях доступа к ресурсам баз данных не только мобильного Интернета, но и к базам информационно-коммуникаиионных систем и сетей. В статье предлагается принципиально новый подход к обеспечению закрытия голосового канала мобильного Интернета на основе алгоритмов постквантовой криптографии - крипто-кодовых конструкциях Мак-Элиса и Нидеррайтера на эллиптических кодах. Такой подход обеспечивает не только офлайн режим закрытия голосового канала и создания VPN-канала в туннельном режиме, но и требуемый уровень криптостойкости в условиях появления полномасштабных квантовых компьютеров.

Ключевые слова: постквантовые криптоалгоритмы, крипто-кодовые конструкции Мак-Элиса и Нидеррайтера, мобильный Интернет, технология 4G, $5 G$. 